Vox Patrum 6/1986/ z.10

\title{
NEOPATRYSTYCZNA SYNTEZA PRAWOSŁAWNA NA PRZYKŁADZIE PAULA EVDOKIMOVA
}

Zrozumienie miejsca $i$ roli myśli patrystycznej w teologil prawosławnej wymaga uświadomienia sobie dwóch ważkich elementów, a mianowicie samego zakresu czasowego patrystyki wschodniej oraz odejścia od linii patrystycznej, zwłaszcza okresie potrydenckim 1 powrotu do tej linil na przełomie XIX 1 XX wieku. Te dwa bowiem elementy odegrały też znacząca rolę wozwoju myśli teologicznej Paula Evdokimova.

Jezeli chodzi o zakres ozasowy patrystyki wschodniej, to podręczniki patrologii dzlelą zwykle patrystyke na oztery okresy: 1. powstanie /do roku $150 /$, 2. dalszy rozwój /150-325/, 3. okres "złoty" /325-460/, 4. schyłek /460-754/. Granice okres6w sa zawsze czymé względnym, ale okres patrystyki wschodniej sięga dalej niz okres patrystyki zachodniej, dla której granicę stanowi scholastyka, nie 1stniejąca w dziejach Kościołów wschodnich. W ten sposób wybitny obrońca kultu obrazów, 8́w. Jan Damasceńsk1, żyjący na przełomie VII 1 VIII $w .1$ mający $w$ swej doktrynie juź wiele cech mý́lenia ́́redniowiecznego, jest przez wszystkich uznany za wielkiego przedstawiciela syntezy dotychczasowej patrystyki wschodniej i za 0jca Kościoła, choć reprezentuje juz pewne cechy typowe dla scholastyki zachodniej. Podobnie, zyjący $\mathbf{X}$. św. Symeon Nowy Teolog nie może być oddzielony od okresu patrystyki wschodniej, - czym swiadczy choćby jego przydomek "Nowy Teolog", stawiający go wezpośredniej relacji jeźeli nie do św. Jana Ewangelisty, zwanego równieź Teologiem, to ważdym razie do św. Grzegorza Teologa. Fakt ten uznaja w całej rozciagłości znaczące serie pism 0jców Kościoła, Jak "Sources Chrétiennes", włązajace jego dzieła 
do swych wydan ${ }^{1}$. To samo mozna powiedzief o pismach wielkiego teoretyka hezychazmu, św. Grzegorza Palamasa. Jego doktryna, szukajaca dla nowego doświadczenia hezychastów wyrazu w kategoriach myślenia kapadocczyk6w, nie czyni go przedstawicielem nowego kierunku, leez średniowiecznym kontynuatorem mýll patrystycznej.

Nie ma rómniez powodu oddzielać od patrystyki wielkich kanonistów średnlowiecznych, Jak Balsamon czy Zonaras, walcząoych o kanoniczne ramy dla tej eklezjologil, która stworzyli 0jcowie Kościola przeciwko mitom anarchloznego splrytualizmu. Należy tu podkreś116, ze kanony Kościołó wschodnich powstały w okresie patrystycznym 1 sa $z$ tym okresem nierozdzielnie zwiazane. Mam tu na mýsli ustawodawstwo soborów powszechnych 1 synodów lokalnych oraz ustawodawstwo biskupów, czyli kanony trzynastu 0jcóm Kościoła/Dionizego Aleksandryjskiego, Grzegorza z Neocezare1, Plotra Aleksandryjskiego,

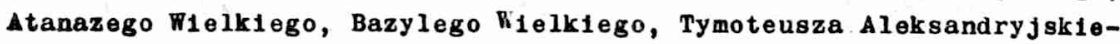
go, Grzegorza Teoluga, Amfilocha z Ikonium, Grzegorza z Nyssy, TeoIlla Aleksandryjskiego, Cyry la Aloksandryjskiego, Genadiusza Konstantynopolita:skiego $i$ Tarasjusza Konstantynopolitarskiego/ ${ }^{2}$. wielcy kanonisci 1 komentatorzy kanonów nie powinni byé sztucznie oddzieland od okresu patrystycznego, waścimego dla Zachodu 1 sztuoznle nałozonego na chrześc1janstwo wschodnie. Trudno pomijá takie nazwiska, Jak Aleksy Arystydes /XII w./, Jan Zonaras /XII w./, Teodor Balsamon /XII $w_{.} /$, Dymitr Chomiatyn /XII $w_{\bullet} /$, Mateusz Blastares /XIV w./ 1 Konstanty Armenopulos /XIV w./.

Takze wybitn1 l1turgífc1, rozwijający sakramentologle zapoczatkowana w okresie 0jców Kościola, trafiaja juz do seril patrystyoznyoh ${ }^{3}$. Równ1ez l1czne komentarze mistagogiczne, zwaszcza do

1 Por. Catéchèses = SCh 96,104,113; Chapitres théolog1ques gnost1quęs et prat1queg $=\mathrm{SCh} 51 ;$ Hymnes $=$ SCh 156,174, 196; Traités théologiques et ethiques = SCh 122,129 .

2 Igh kanony zebral 1 nydaz ostatnio P.P.Joannou, Discipline géneralo antique /IVe-IX $\mathrm{IX}^{\theta} /$, t.2: I $9 \mathrm{~s}$ canons des Peres Groes, Grottaferrata 1963 s8.00XV + 332 .

3 Por. Nicolas Cabasilas, Bxplication de la difine Liturgie = SCh 4 b1s. 
liturgil eucharystyeznej, mimo swych licznych brak6w, jak zbytnie rozwijanie symbolizmu liturgicznego, są kontynuacją mýsll patrystycznej. Dotyczy to zwraszcza "Mistagogiin" św. Maks sma Wyznawcy/napisanej 628-630/, prac 6́⿴囗十 Symeona z Tesaloniki /+1428/, patriarchy Konstantynopola ́́w. Germana $I /+733 / 1$ innych ${ }^{4}$. Trudno tez pomijać tu sama liturgie Kościołón wschodnich, powstała prawie v caYośc1 w plerwszym tysiącleciu chrześcijaństwa. Jej pomijanie w opracowaniach dotyczacych patrystyki jest duży nleporozumieniem, gdyz Ojcowie wschodni byli insplrowani przez liturgie nie tylko w zyciu wewnętrznym, ale 1 w budowaniu teologi1. Liturgia, bogata wiewyczerpane wrecz głębie perspektyw teologicznych, stanowi źródło 1 podniete dla przeżć mistycznych oraz dla twórczośc1 teologicznej. Jezeli od patrystyki nio oddziela sie poezji ojców, to tym bardziej nie nalezy oddzlelać liturgil, której powaźną część stanowi przecieź poezja 0jców Kościoła. Wystarczy tu przypomnieć niedzielne oficjum ośmiu tonów, zwiazzane ze św. Janem Damasceńskim, a także poezje 11turgiczną św. Grzegorza, św. Romana Melodosa, f́w. Andrzeja z Krety, ám. Kosmy z Majum 1 1nnych.

Granica patrystyki zachodniej jest wyraźna 1 siega scholastyk1. Scholastyka jednak nie rozwinęła się n1gdy w pełni na Wschodzie. Podjeta przez Michała Psellosa /+ 1078/ oraz Jana Italosa /+ 1082/ próba spekulatywnego wyjaśnienia dogmatów wiary oparciu m.1n. - aryetotelizm, zakończyła sie niepowodzeniem, a sam Italos został - $1082 \mathrm{r}$. potępiony za podporzadkowanie dogmatu filozofil. Podony 108 spotkal tez przecinnika św. Grzegorza Palamasa, Barlaama z Kalabri1.

Dop1ero upadek Konstantynopola w $1453 \mathrm{r}$. spowodowal obumarcie tego podłoza, z którego wyrosła wspólna dla całego wschodniego chrześc1jaristwa myśl patrystyozna. Odtąd chrześcijański Wschód został pozbawiony uniwersalnego centrum kulturalnego, którym dla niego była Grecja. W poszczególnych Kościołach mogli nadal działaó kontynua-

4 Por. R.Bornert, L'anaphore dans la spiritualité liturgique de Byzance. Le temoignage des commentaires mystagogiqueg du VII au Xvesiecle, w: Eucharistie d'Orient et d'oecident, t.2, Paris $1970,241-263$; R.Bornert, Les commentaires byzantins de la Divine liturgie du ve au xie siécle, Paris 1966 /Archives de 1'0rient Chrétien $9 \%$ 
torzy mý́li patrystycznej, lecz brakło jej pręznych przedstawicieli, mających jak ojcowie, niezaprzeczalny autorytet dla całego Kościora.

Wtórną przesłanką, potwierdzającą załozenie, ze rzeczywiście tytuł "Ojcowie Kościoła" moze byé stosowany do pisarzy zyjących po 6́w. Janie Damasceńskim /+749/ są fakty następujące: uzywanie tego tytułu przez samego Jana Damasceńskiego odnośnie do pisarzy - swoich bezpośrednich poprzedników, który przy nich pozostał ze względu na ich wielki autorytet oraz uprawianie długo jeszcze po nim tej samej teologi1.

Pouczający jest tym mzględzie rozwój kultu ikony "Kośc1ele, którego teologiczne podstawy zostały sformułowane w szacie słownej podczas kontrowersj1 ikonoklastycznej w clągu VIII wieku. Sama jednak ikona znalazła swój pełny wyraz dopłero pod wpłyøem działanla ozywczej rosy, do której w myśl tego, co św. Jan Damasceński pisze o epiklezie eucharystycznej, mozemy przyrónać teologie Ducha Swiętego, rozwinięta przez takich pisarzy, jak św. Symeon Nowy Teolog w IX wieku. Przenosząc więc granice patrystyki zachodniej na zycie Kościoła wschodniego, można mieć mątpliwośc1, czy równiez zywot lkony ma jeszcze jakiś związek z okresem patrystycznym. Pokazuje to, jak bardzo konwencjonalne sa wszystkie podziały 1 niekiedy mało uzasadnione, zwłaszcza jezeli sztucznie nakłada slę granice czasowe na inny obszar kulturowy ${ }^{5}$.

Faktem, który 1stotny sposób zmienit sytuację na wochodzie, by 1 upadek Konstantynopola oraz trwajace kontrowersje z Kościołem rzymskim, a później protestantyzmem. Spowodowało to zaniknięcie kontaktu z myślą patrystyczną 1 przejecie wzorów teologicznych Zachodu. Opracowano przy tym swoista metodę apologetyczną, polegajacą na zwalczaniu pozycji katolickich przy pomocy argumentón protestanckich 1 odwrotnie. W tym tez okresie rozwinęło sie na szeroka skale opracowywanie szkolnych podréczników teologil, pisanych chu scholastycznym 1 stojących ozesto niestety na niezbyt wysokim

5 Por. H.Paprock1, Terminus ad quem patrystyk1 wschodniej, "Wiadomośc1 Polskiggo Autokefalicznego Kościoła Prawosłannegón 12/1982/ z.3-4, 92-95; J.Meyendoref w swej pracy "Vvedenie vovjatootceskoe bogosiovie, New York 1982, zamieszcza omówienie spuścizny patriarchy śr. Focjusza, św. Grzegorza Palamasa 1 Mikołaja Kabasilasa. 
poziomie. Georges Florovaky caly ten tragiczny 1 mało twórczy okres " dzlejach mý́li teologicznej Wschodu nazwał miewola babilonską" ${ }^{6}$. Przebudzenie nastapiło dopiero w XIX wieku.

Paul Evdokimor nie jest więc pierwaym teologiem prawosławnym, który zwrócil się do 0jców Kościoła. Naleźy tu wczé́niej wymienic przede wszystk1m Aleksego Chomiakowa /1804-1860/, kt6ry zdeoydowanie odszedz od schematów szkolnej teologil. Przełom zaś XIX 1 XX w. zaowocowal tutaj cała plejada mý́licieli, z których zwaszcza wymiení należy Whodzimierza Sołowjowa $/ 1853-1900 /$, Pawła Florenskiego /1882-1943/ I Sergiusza Bułgakowa/1871-1944/, który sam nazywał swoja teologie "neochalcedońską". Równiez Georges Florovsky /1893-1979/ nawlązywał często do 0jców Kościoła 1 tworzył syntezę teologiczna o charakterze neopatrystycznym, podobnie jak Sergiusz Bułgakow. Jednakze Paul Evdokimov, jak saqdze, zasługuje tutaj na szczególnaz uwagę. W sposób twórczy bowiem zasymilowal myśl ojców oraz elementy róznych tradycji naukowych współczesnego świata wyntezle nlezwykłej, będącej być moźe największym dziełem prawosławia $X X$ wieku $^{7}$. Istotna w tym role odegrała droga zyciowa Evdokimova, która go skierowała ku takiemu właśnie, trórczemu dialogowi z mý́la patrystyczna.

Paul Nikolaievitch Evdokimov urodził się w 1901 r. Petersburgu 1 poczatkowo, zgodnie z tradycjami rodzinnymi, zamierzaz poświecí́ się karierze wojskowej. Ukończył nawet szkołe kadetów, przebywająo jednak $1918 \mathrm{r}$. W Kijowie, rozpoczą studia w tamtejszej Akademil Duchownej. Jak wielu mu współczesnych emigrował $1920 \mathrm{r}$. do Istambułu, a następnie przez Belgrad, Pragę 1 Berlin dotarł do Paryż, gdzie w latach 1924-1928 odbywał studia filozoficzne na Sorbonie oraz teologiczne w Instytucie św. Sergiusza, głónnie pod kierunkiem S.Bułgakowa, G.Florovskiego 1 N.Bierdjajewa. W latach 19241942 przygotowywaz rozprawy doktorskie z dziedziny teologil 1 11lozo111. Zajmowax się wówczas także myślą Dostojewskiego, analizująo twórczość tego wielkiego pisarza rosyjskiego na tle nauki prawosıamnej, tym równiez patrystycznej ${ }^{8}$. W 1953 r. został kierownikiem ka-

6 Por. Puti russkogo bogoslovija, Paris 1937, 19812.

7 o.clément, Préface, w: P.Evdokimov, La femme et le salut du monde, Parts $1978^{2}, 7$.

8 Por. Dostoî́rsky et le problème du mal. Paris 1978 ${ }^{2}$; Gogol et 
tedry̆ teologil moralnej " swojej alma mater Instytucie św. Sergiusza w Paryzu, z którym pozostał zwlazany az do śmierc1, czyli do $1970 \mathrm{r}$.

Opublikowane prace Evdokimova mozna podzielié na pięć kategoril.

1. Ksiązki ogólnie informujące, jak np. "L'Orthodoxie, Neuchatel $1959^{9}$.

2. Dzieła ścíle dogmatyczne, Jak: La connalssance de Dieu seIon la tradition orientale, Lyon 1964; L'Esprit Salnt dans la tradition orthodoxe, Paris 1969.

3. Dzieła o tematyce moralnej 1 antropologicznej, jak: Sacrement de l'amour, Paris 1962; La femme et le salut du monde, Paris 1958, $1978^{2}$.

4. Stud1a kulturoznawcze, jak: Dostolevsky et le problème du mal, Lyon 1942, Paris $1978^{2}$; Gogol et Dostolevsky ou la descente aux enfers, Paris 1961; Le Christ dans la pensée russe, Paris 1970.

5. Studia o teologicznej roli piekna 1 o liturgil, jak: L'art d'icône. Théologie de la beauté, Paris 1970; La prière de l'k̂glise dorient. La liturgie de saint Jean Chrysostome, Paris 1966.

We wszystkich tych pracach, a takze w opublikowanych artykuzach, Evdokimov nawlązywał do myśl1 patrystycznej. Onszem, mozna powiedzieć, ze mýs patrystyczna była zawsze punktem wyjócia wszelkich jego poszukiwań teologicznych. Dazyl bowiem do zintegrowania tradycj1 patrystycznej az do Grzegorza Palamasa i Mikołaja Kabasilasa wacznie z tradycja duchowośc1 Philokalil oraz a intulcjami wielkich rosyjskich fllozorów religijnych 1 współczesnych mý́licieli zachodnich, Jak Karl Gustav Jung, Pierre Teliharde de Chardin, Albert Camus, Jean-Panl Sartre, s1ęgajac przy tym zarónno do teologil katolickiej/Teilhard, Congar/, jak 1 protestanckiej/Barth, Bultmann/. Chcial przez to osiągnác profetyczna synteze zintegrowanz z inspiraoji patrystyoznej. Fenomenu takiej integracji próbowało juz weześniej dokonać wielu mýslicieli na Fschodzie, jak: Ewagriusz, Oryge-

Dostopiersky au la descente aux enfers, Paris 1961.

9 Przezozył Ja J.Klinger, Prawosławie, Warszawa 1964. 
nes, tradycja Pseudo-Areopagiticum, Grzegorz Palamas, Nikodem Hagloryta 1 inni. I chociaz Erdokimovowi moźna zarzucić pewien eklektyzm, to jednak nalezy zaurażć, ze stworzył on oryginalna 1 twórczą syntezę, posiadajaca swoisty rytm 1 skierowaną ku sprawom Ducha. Sam pojmowal teologie jako rodzaj wewnętrznej muzyki, w którą się ciaggle wsłuchiwał. Był przy tym otwarty na zagadnienia wapółczesne, a jego dzieła wykazują wręcz niezliczone powiązania z mýlą ogólnoeuropejska.

Tylko w dwóch swolch pracach - "Sacrement de 1 'amour" /Paris 1962/ oraz "Les âges de la vie spirituellen/Paris 1964/ - Erdokimor cytuje 55 ojców Kościoła, począwszy od 0jcб́w Apostolskich az do Mikołaja Kabasilasa, nie liczac przy tym tekstóm liturgicznych, prawniczych, poezj1, apokryfów, reguz zakonnych, decyzji soborów 1 synodów, apophtegmata patrum 1 zywotón swiętych. Nie jest to jednak tylko cytowanie tekstów patrystycznych. W tym chórze róznych głosбw występuja tez współczéśni nam mý́liciele, a takze śm. Tomasz z Akwinu, św. Bonawentura, Luter oraz sam Evdokimov, który prowadz1 z 0jcant Kościoła dialog twórczy. I to właśnie najbardziej rózni dzieło Evdokimova od Innych prób syntezy neopatrystycznej, chociazby Florovskiego. 0 lle bowiem synteza Florovskiego ma charakter statyczny 1 cała zwrócona jest ku przeszłośc1, o tyle Paul Evdokimov budował syntezę dynamiczna, otwartą na człowieka mspółczesnego i na jego problemy. W tym tez należy upatrywać znaczenie jego utworów.

Wielkość Evdokimova tkwi włodości jego myśl1 1 zdolności do integrowania wielkiej tradycji patrystycznej, palamickiej i filokal1cznej. Dostrzegając profetyczność tradycji, Evdokimov dokonat wielkiej syntezy z Inspiracji patrystycznej. W duchu 0jcór Kościola starał się odporiedzieć nawet twórcom mý́li współczesnej - Marksom1, Nitzschemu 1 Freudowi. Fenomen integracj1 kończyl się często - Kościele potępieniem jego autorów, jak na przykład gnozy Bwagriugza 1 apokatastazy Orygenesa. Integracja Evdokimova miała jednak Inny, oczyszczający charakter, a kaźda intulcja autora została powiązana z tradycją. Evdokimov śwladomie aktualizował tradycje, Jak gdyby kierował sie hasłem: "Naprzód w kierunku 0jcóm Kośc1okan. Od czasón Bułgakowa, Florovskiego, Losskiego 1 Evdokimova, teologia neoscholastyczna straciła w prawosław1u swoj sens. Sam Evdokimov niesłychanie rzadko cytowal teksty teologow oficjalnych z okresu "niewoli babilońskiej", a jedyny wyjatek stanowil tutaj 
- chyba metropolita Filaret Drozdow/1783-1867/. Twórczy Iadunek dostrzegał autor pracy "L'art de l'1cône" nie w szkolnej teologi1, ale w dziezach 0jców. Cytaty z Ich pism zawarte w jego pracach nie miały na celu usprawiedliwienta jego wasnej argumentacji, ani nie były argumentami płynącymi od autorytet6w, ale były słowami - nasionami, które przesycają tekst 1 ukazują wspólnotę. W tej communio patrum Evdokimov dostrzegał młodość 1 śwleżość tradycj1. Preferował w tym oczywíście niektórych 0jców Kościoła, Jak kapadocczyków, Maksyma Wyznawce, Symeona Nowego Teologa, Grzegorza Palamasa 1 Mikozaja Kabasilasa. Tego ostatniego często cytowal z powodu jego nieustannej medytacji nad szaloną miłością Boga ku człowiekowi - mantkos eros.

Wyjácie od 0jców Kościoła pozwoliło tez Evdokimovowi rozpatrywać Kośció jako Eucharystię, realizująca sofianiczność stworzenia, gdzie wszyscy ludzie sa wezwani do zjednoczenia woḱ́ł jednego kielicha. Jego myśl jest zawsze eklezjologiczna 1 nastawiona na spotkanie ze Zmartwychwstałym. Mozna powiedzieć,ze metoda jego pracy była "eucharystyczna" - - Jednośc1 rzeczy świętych 1 wspólnoty świętych. Kośc1ół był dla niego Eucharystią 1 wolną wspólnotą w Duchu $i$ w tradycji jako anamnezie Żyjącego, świat zaś krzakiem gorejącym 1 misteryjną 1kona Boga. Zawsze dązył do stworzenia pewnej organicznej syntezy mysli patrystycznef 1 mysli wspołczesnej. Budując antropologie trynitarną nie zapomniał o antropologii eklezjalnej, ukierunkowanej ku aktywnej eschatologii, w której kazda liturgia eucharystyczna staje sie ikoną Królestwa Niebieskiego. O jego umiejętności tworzenia otwartych syntez świadczy najlepiej kwestia epiklezy, czyl1 modlitwy przyzywającej Ducha Świętego, gdzie rozszerzając twórczo mý́l бw. Bazylego o epiklezie jako nieustannym apelu o jedność Kościoła 1 d́wata, dostrzegł niej, w tym najbardziej kontrowersyjnym problemie dzielącym Wschód 1 Zachód odnośnie Eucharysti1, wymiar ekumeniczny ${ }^{10}$.

10 Por. O.clément, La vie et l'oeuvre de Paul Evdokimov, "Contacts" 23/1971/z.73-74, 11-106, zwłaszcza s. 28-43; J.K11nger, Pawel Evdokimov, świecki teolog prawosławia, "Kierunki" 16/1971/ nr 3; M.Klinger, Evdokimov Paul, EK IV, 1363-1366; J.S.Gajek, Il mistero della Chiesa nel pensiero di Pavel N. Evdokimov, Roma 1983; G.S.Gajek, La Chiesa domestica in una prospettiva orientale, Roma 1984 . 
Wracając do tego, co ośmieliłem się na początku mego wystąpienia poriedzieć o granicach czasowych patrystyki w prawosławiu, sądzę, ze syntezę teologiczną Paula Evdokimova chyba niesłusznie nazywamy "neo-patrystyczną". Termin ten bowiem uszczupla niejako bogactwo myśll Evdokimova, powiazanej z całą rozległością współczesnej problematyki teologicznej 1 filozoficznej, z którá Evdokimov prowadziz nieustanny dialog. Jest tez w tej postawie Evdokimova wiele z odwagi ojców Kościoła, którzy nie oglądali się tylko wstecz, ale zawsze.prowadzili dialog ze współczesnym im światem. Evdokimov, jak sądzę, pozostał wiernym synem tradycji 0jcón 1 stosował ich metody " smojej pracy naukowej. Odważnie prowadził dialog z mý́lą mspółczesnego świata, a jego zdolność opracowywania syntez jest wprast zadz1wiająca.Moźna jedynie wyrazić zal, ze na język polski została przełozona jedynie ogólnoinformująca praca o Kościele prawosławnym "L'Orthodoxie", wtórej chyba najmniej dostrzegalna jest jego zdolność tworzenia zamkniętych syntez, a w oczy rzuca się raczej pewien eklektyzm 1 dąźność do zaprezentowania istniejącej doktryny. Inne prace Evdokimova, zwaszcza poświęcone roli kobiety wistoril zbawienia świata, sakramentowi małzeństwa, miłości Boga ku człowiekowi czy tez etapom zycia duchowego, są bardziej reprezentatywne dla jego prawdziwej myśli. W nich teź doszła wełni do głosu jego zdolność do tworzenia syntetycznych ujęć określonych problemów, jak na przykład "Kobieta 1 zbamienie świata". Dzieło Evdokimova, jak prawie wszystkie próby tworzenia zamkniętych syntetycznych systemów, nie zostało zakończone, ale kilkanaście tomów jego prac stanowi rzadki w dzisiejszym świecie dorobek syntetyzujący myśl róznych epok w organiczną całość. W centrum jednak tej syntezy sto1 zawsze Pismo Śrięte 1 tradycja Ojców Kościoła. To właśnie wszystko pozmala stwierdzić, ze Paul Evdokimov stworzył syntezę teologiczną o charakterze patrystycznym, której znaczenie, jak sądzę, będzie ciągle wzrastać, a zarazem stanowié wzór dla przyszłych dociekan teologicznych w prawosławiu.

$$
\text { K8. Henryk Paprock1 - PSD Tarszawa }
$$

\section{LA SYNTHESE NEOPATRISTIQUE DE PAUL EVDOKIMOV
/Résumé/}

L'auteur dans la première partie de cette article analise 108 problèmes de la ohronologie des périodes patristique en l'orient et 
ensuite caractérise la pengéé de Paul Evdokimóv/1901-1970/. Théologien orthodoxe Prança1s? d orlgine russe, Paul Evdokimov, dans ses grandes ouvrages thélogiques est enreoiné non seulement dans la. patristique orientale et occidentale, mais aussi des problemes d auJourd hui et élabore une synthèse profondément orthodoxe ot ouverte jour les problèmes 'e notre époque, comme l oecuménisme, le féminisme, íart de l icône et la théologie sacramentaire. Il faut croire, que la synthèse néopatristique de Paul Evdokimov est un érénement non seulement dans le monde orthodoxe. 